\title{
Migration to the Republic of Slovenia as "A First Step" into the European Union
}

\author{
Liliana Brozic \\ Faculty for Government and European Studies, New University, Slovenia \\ Received November 19, 2019; Revised April 1, 2020; Accepted April 19, 2020
}

Copyright $\subseteq 2020$ by authors, all rights reserved. Authors agree that this article remains permanently open access under the terms of the Creative Commons Attribution License 4.0 International License

\begin{abstract}
As a member of the European Union during the European migrant crisis in 2015, the Republic of Slovenia found itself in a crisis situation as a small transit country through which many thousands of migrants travelled. Although it had already experienced with migration, as a result of the wars in the Balkans, in 2015 it was extreme. The nation integrated all its capabilities, including the armed forces, with the support of other member states. As Slovenia is one of the first countries of entry into the Schengen area, there is a growing trend in the country for various forms of migration, including economic and illegal, as well as refugees looking to Slovenia for asylum. Increasing migration for a small country poses a major security challenge. This article focuses on a small country as a member state of the European Union, which urgently needs change and a broader political and security framework to cope with increasing migration demands. It needs more input from the European Union in the future.
\end{abstract}

Keywords European Union, Migration, European Migrant Crisis, Small States, Republic of Slovenia, Slovenian Armed Forces, Illegal Migrations, Asylum Seekers

\section{Introduction}

The Republic of Slovenia is a small country surrounded by Italy, Austria, Hungary, Croatia, and the Adriatic Sea. Before its independence in 1991 it was part of Yugoslavia. Since 2004 it has been a member of the European Union (EU) and NATO. Its border with Croatia became a Schengen border in 2007; the southern border of the EU, looking towards the countries of the Western Balkans.

In 2015 Slovenia had to protect its own border and the border of the EU at the time of the European migrant crisis; it was a very demanding task for a small country with finite resources to host approximately 400,000 people crossing its borders. To deal with this issue a comprehensive approach and the coordination of all the country's available resources, including the military, was required.

The term migration ${ }^{1}$ can be defined as the crossing of the boundary of a political or administrative unit for a certain minimum period of time. It covers the movement of refugees and displaced or uprooted people, as well as economic migrants.

This article presents the migration trends in the Republic of Slovenia before the European migrant crisis of 2015, during the time of the crisis, and in the period thereafter. All the trends are supported by different articles and by government-released data [for more see the References].

Migrant flows into the EU became a full-blown union-wide humanitarian and political crisis in the autumn of 2015. Individual countries in the Mediterranean area had had problems with migrations from North Africa as consequences of the Arab Spring which started in 2010, but this was largely addressed unilaterally, e.g. in Italy. Greece became the country with the highest migration pressure later, in 2015, when the "Balkan route" had huge numbers of migrants looking to Europe (especially Germany, Austria and Sweden) to find a better place and living conditions. Originally, the Balkan route went towards Hungary, the nearest Schengen border, but when Hungary physically closed its borders, the route for migrants shifted west through Croatia and then towards Slovenia as the next Schengen border [1]. The first wave reached the Slovenian border on 14 September 2015. The wave was expected, but the sheer numbers overwhelmed Slovenia's expectations and preparations, in spite of its previous experience with mass migration during the war in Bosnia and Herzegovina in 2000 and 2001.

1 See the UNESCO definition: https://wayback.archive-it.org/10611/20171126022441/http://www.unesc o.org/new/en/social-and-human-sciences/themes/international-migration/ glossary/migrant/ 


\section{The Republic of Slovenia as a Small State in the European Union}

The unitary parliamentary republic of Slovenia has been independent since 1991. It is an ex-republic of former Yugoslavia, and was the first of the six Yugoslavian republics to vote for independence. The Republic of Slovenia became a member of NATO and the EU in 2004. Its border with Croatia is the southernmost EU border, and the enforcement of Schengen borders must be very strict because once across and within the $\mathrm{EU}$, there are no further border controls; there is complete freedom of movement within the EU for both its members and for visitors once they are inside. We can understand this fact as the main reason why migrants wish to cross this border, legally or illegally, as "a first step" into the EU, although, of course, the neighbouring Republic of Croatia is also a member state.

Slovenia is small (20,273 square kilometres), with a population of some 2 million people. In this regard Mikuž [2] argues that size matters. From an institutional point of view, the great powers are those in charge of the international system, and they shape international institutions accordingly. This institutional privilege is seen in the composition of the United Nations Security Council. International institutions require justification through the formalization of norms and rules for the use of power, which are recognized by small states as a primary value in the area of international law and as a regime where even small states have a say. Small states may be defined by a quantitative lack of power in dimensions such as population size, geographical area and Gross Domestic Product (GDP), although some small states may have 16 million inhabitants, such as the Netherlands, and others only 100,000 . Some may be recognized as small by a lack of international power.

Lulle and Ungure [3] also consider Latvia, with a population of 1.9 million and an area of $64,589 \mathrm{sq} \mathrm{km}$, as a small state. Like the Republic of Slovenia, Latvia declared its independence in 1991 and joined the EU in 2004. In past decades Latvia gained some rather fragmentary experiences of welcoming asylum seekers and granting the status of protection. In the period between 1998 and 2014, 1,440 applications for asylum were received, and 364, reported in 2014, was historically the highest. The Latvians responded by debating fear and security concerns, having in mind that in the history of Latvia their sovereignty and their very existence had been threatened by the Russians. The Latvians were an independent country some decades ago, between the two world wars. The authors analysed many of the public reactions in the media with an emphasis on the fear and anxiety that the migrants caused among the population.

We can assume that Slovenians have felt threatened by many other nations throughout their history, although independence in 1991 was the first time that compared with
Latvia. Slovenia had already had experience with migration flows in the past; Kralj [4] references the migration crisis in the Republic of Slovenia in 2000-2001, as a consequence of the war in Bosnia and Herzegovina, which included 31,000 illegal migrants wedged at the southern Slovenian border by the police. As Kralj states in her article, the results of a survey on Slovenian public opinion in 2005 indicated that migrants and asylum seekers were seen at that time as a threat to national security. Approximately $70 \%$ felt that migration needed to be limited, and approximately $20 \%$ responded that it should be strongly limited. So we can see that Slovenia had had experience with migrants even before it became an EU member, although we believe that after its accession the country became even more desirable to newcomers.

In the autumn of 2015, 334,838 illegal migrants crossed the Slovenian border and entered the country. Of these, 166,136 were from Syria, 109,211 from Afghanistan and 59,491 from Iraq. They also included people from many other countries whose total numbers were not so significant [10].

As the migrants in 2015 went through the Balkan route, they passed through Macedonia, Serbia, Croatia, and finally Slovenia. According to Šelo Šabić [5], none of these countries felt they had any responsibility for the migrants, or any ability to solve the crisis themselves. She emphasized that Slovenia complained of the lack of co-operation with Croatia. The Slovenian prime minister and government demanded a special meeting in Brussels of all the countries along the Balkan route, together with the other members of the $\mathrm{EU}$, to find ways for better co-operation, with the aim of normalizing the pressure on small countries in the region which could not cope individually, or even collectively, with the processing of such huge numbers of people and the need to take care of them on a daily basis. The meeting concluded with a 17-point action plan which improved co-operation between neighbours, but Slovenia stressed that it had the added burden of needing to protect its own border, as well as that of the EU.

In discussing the effects on small states during this migration crisis we need to highlight the fact that the perception of a small country may vary. Luša [4], in her article, makes a comparison between four small states: Croatia, Slovenia, Austria, and Sweden. The first two of these were transit countries, but the latter two were destination countries. The former has numerous geographical challenges arising from their small land masses, fragmentation, remoteness, and isolation. Luša [6] emphasized that on top of this came social challenges resulting from small populations, limited institutions and human capacity, and economic challenges due to the limited size of domestic markets, openness, concentration of exports, and a strong dependency on the global economy.

Many in Slovenia understood the humanitarian nature of 
the migrant crisis in 2015, which explains why so many humanitarian organizations immediately organized everything necessary to help the government cope with the situation. As Garb [7] noted, the regular work of all the government and other institutions involved in the response also had to be carried out, as well as their work supporting migrants. There was also a police strike during the crisis, and they had to continue their urgent work in spite of the strike. Personnel resources, therefore, were significantly diminished.

The very first response in Slovenia was a humanitarian one, but later, when the masses of migrants became bigger and, according to Garb [7], more difficult (e.g. violent quarrels, setting fire to a reception centre and mass violation of public order), the second response was a security one. At that time Svetlič [8] wrote that in a humanitarian crisis, the protection of migrants and refugees is the most important responsibility of the state, but when the state itself is in danger because the numbers of the migrant flow are too great, then the state needs to primarily protect its own citizens and enforce the law. The issue of security issues related to the migrant flow [9] appeared in the media quite late, only in December 2015. Before that time, the migration was most often framed from an informational, political, human rights, and social viewpoint; however, by the end of the year the security issues of the crisis had come to prevail.

\subsection{Slovenia as Part of the EU Common Security and Defence Policy}

Ceccorulli and Lucarelli [10], in their article of 2018, demanded an answer to the dilemma of whether, with regard to the situation in Slovenia, the EU wants to secure its borders or to protect the migrants, a question which had already been highlighted in 2015 by its political leaders with a request for more cooperation between the EU members.

Migration was, until recently, a secondary preoccupation of EU policy. It has gradually been securitized, not as the result of an explicit act of securitization of the issue per se, but as an ancillary and derivative component of policies within Justice and Home Affairs, particularly in response to internal and external challenges or the integrity of the Schengen area and freedom of movement. Ceccorulli and Lucarelli concluded that some policy developments were not the result of strategic planning on migration, but were instead part of a larger response to challenges to public safety. They emphasized that migration had scarcely been alluded to in earlier EU documents, and that migrant outflows were mentioned only as a consequence of competition for natural resources due to accelerating climate change. We can see that the EU migrant crisis of 2015 found both the $\mathrm{EU}$ and its member states politically surprised and completely unprepared. Migration was not yet part of the
EU Common Security and Defence Policy, which led to the unthinkable situation where members of the Slovenian Armed Forces had to deal with the migrant flows as a support to the police, even though they had never imagined doing this kind of task in their own homeland. Resteign and Manigard [11] analyzed the phenomena of the "policization" of the armed forces as the new normal in the case of Belgian defence in 2015, where its military personnel were deployed in the streets to support the police in response to imminent terrorism.

The Slovenian Armed Forces were present at the Schengen border to protect and escort the illegal migration through the country, and the unexpected mission was not planned to last. Ceccorulli and Lucarelli [10] stressed that the European Agenda on Security (EAS) in April 2015 concerning internal security, and the EU Global Strategy of 2016, consolidated the strategic relevance of migration. The 2010 Internal Security Strategy and EAS did not consider external borders in conjunction with terrorism, organized crime or cybercrime, but instead treated migrations as a specific and discrete security concern, which was included in the 2015 European Agenda on Migration (EAM). Thereafter the EAM complemented the EAS by addressing the smuggling of migrants, human trafficking, social cohesion and border management as issues directly relevant to security.

Ceccorulli and Lucarelli also stated that the EU documents never mention migration as a "threat", as in its own terms of the strategic language of security it should, but it is rather referenced as "a challenge". The EU Global Strategy linked the success of the EU in meeting its key strategic objectives to ensuring that external policies and instruments were "migration-sensitive". The Strategy paid attention to policies that could mitigate migrant flows from origin and transit countries, and recommended that the EU and its member states employ a variegated set of measures to challenge the root causes of forced migration, to share migration management, and to cooperate in fighting trans-border crime, with an emphasis on humanitarian assistance and capacity building, readmission and return. What the authors recognized as the most important message in the EU Global Strategy was the necessity for a more effective common European asylum system, respectful of the rights of those seeking protection, although their arrival should be regulated and legal. The Common Security and Defence Policy (CDSP) [12] of the EU recognizes itself as a useful tool in assisting the $\mathrm{EU}$ and its member states in the management of migration flows. In many CSDP missions and operations migration is implicitly mentioned in the mandates, although the CSDP is mainly focused on security issues in helping its member countries to manage migratory flows at their borders. The CSDP could work alongside the European Border and Coast Guard Agency as well as other specialized EU agencies to enhance border protection and maritime security with the objective of 
fighting cross-border crime and disrupting smuggling networks and thus saving more lives.

Possible areas for enhanced CSDP support could include: border surveillance and the prevention of uncontrolled border crossings; the processing of irregular migrants; law enforcement activities; and reform of the security sector.

One of the ways in which the EU could offer help to its member states is in establishing clearing-house functions at the EU level in order to have a very clear idea of the national, bilateral, multilateral and regional initiatives. Another way would be to refer to Article 222 of the Treaty on the Functioning of the EU, the so-called "solidarity clause". The procedures for its implementation are in place and could be used immediately. The EU must mobilize all the instruments at its disposal, including the military resources made available by the member states [12].

In the period between 15 October 2015 and 25 January 2016, 422,724 migrants crossed into Slovenia. In October alone there were 12,616 of them, with an average 7,877 migrants a day. Later, there were 5,477 in November, 3,116 in December and 1,986 in January 2016 [13].

Such a high number of migrants quickly became a huge burden on such a small and unprepared country, which had to escort all the migrants through its territory. On average, some 450 members of the Civil Protection Service, members of humanitarian organizations, and private volunteers took care of them. Between 500 and 1000 police officers and 460 soldiers were there to monitor and protect the mass migration on a daily basis $[1,13]$.

The Slovenian Police and the Armed Forces had approximately 8,000 members each in autumn 2015, but as these numbers were insufficient to the task, foreign police forces from other EU countries came to provide assistance. Most of them were from Hungary (52), Poland (30), Romania and Estonia (25), Germany (22), Lithuania, Latvia, Slovakia, the Czech Republic, France, Austria and Bulgaria [13].

\subsection{The Slovenian Armed Forces and Its Role in the Migrant Crisis}

Dealing with the refugees and migrants in European states and under EU law is a law enforcement responsibility, not a defence one. The Ministry of Internal Affairs is the lead ministry and co-ordinator of the response to the migration crisis. That said, Garb [7] writes that despite that fact, small states and those with limited resources in particular must perforce use all the resources available. Bellais [8] sees the use of the military as one of two dimensions that can be used to achieve an asymmetric strategy, i.e. resources, selecting military means to overcome a quantitative or a qualitative inferiority (the other dimension is strategy, allowing some military surprises by using weapons and human resources in non-conventional ways).

Garb [7] wrote that it is clear that the Slovenian government used a comprehensive approach in tackling the crisis. Concerning the need for a comprehensive approach in both defence and border security, Bellais [8] argued that even a "walled world" would not stop determined migrants, whether for political, security, or economic reasons. Studies on walls and barriers underline that they reduce the number of arrivals or, in the medium perspective, change the pattern of refugee and migrant flows. Nevertheless, repressive tools must be augmented by positive policies (i.e. incentives) that reduce migratory pressure. Hence, it needs a comprehensive approach to the problem.

In the case of the migrant crisis, the activation of the Slovenian Armed Forces (SAF) to support the civil protection service and later the police was clearly in accordance with the law. A comprehensive approach demands that different kinds of actors work together. The SAF was properly trained to support the police during the crisis because they had experience from conducting international operations together. Garb [7] continues that it was mostly the military police who supported the civilian police in their work with migrants in accommodation centres. Later the SAF began to conduct specialized training for parts of its units to support police work, but the military constantly worked under the full authority of the civil protection service and the police. During the crisis, issues of cooperation arose due to standards and habits, and in consequence many adjustments had to be made.

\section{European Union: The Need for More}

Cottey [15] understands the CSDP as an institution without a strategy. The focus on migration policy has shifted from the task of preserving the EU's border security to protecting European societies from massive and unregulated migration that could potentially destabilize European societies and undermine the Schengen system, and preventing the loss of life of migrants crossing the Mediterranean or their exploitation by smugglers. He emphasizes that the EU is not an autonomous security actor vis-á-vis its member states. The EU partially succeeded in the attempt to achieve more autonomy in securing the common border through the creation of the European Border and Coast Guard Agency, but the Agency is less ambitious and autonomous than originally planned. The EU has succeeded in reducing irregular immigration via the Balkan route through the EU-Turkey Statement, although even in this case the agreement was negotiated by the member states rather than the EU's institutions. He concludes with the statement that the overall effect is frequently a stark divorce between what the EU says (which mostly derives from the values it supports) and 
what it actually does. After all we have seen so far the question is, do we need more input from the $\mathrm{EU}$ in the area of the CSDP with a stress on migration?

\section{Researching the Problem of Migration in the EU's Small States}

We have analyzed and compared articles on the EU, the CSDP, migration, and the European Migrant Crisis of 2015 with an emphasis on the Balkan route, which have included Slovenia as a small state and as a case study. We wanted to synthesize different approaches, views, and findings on the issue to ascertain how the EU can deal with migration, especially irregular migrants, and the preparedness and response of small states like the Republic of Slovenia.

All the statistical data on migration, legal and illegal, and asylum seekers with part-time or permanent permission to work in Slovenia, were accessed on the police website of the Ministry of Internal Affairs. The comparative analyses were made from many different viewpoints. We paid special attention to the data of the countries that the largest numbers of people came to Slovenia from across different periods of time.

The countries of origin were more or less the same over the years, but the numbers differed considerably. The first period that we focused on was before the European migrant crisis of 2015, specifically from 2007, when the Schengen border commenced, to 2015. Slovenia has dealt with illegal migrants before. The second period was that of the crisis of 2015, and the third and final period we considered was the years and trends from 2016 to 2019.

Our ambition was a comparative analysis between some of the countries on the Balkan route with an emphasis on migration, but the lack of quantitative data and different approaches to their assessments disabled a quality approach in this regard.

We believe that it is essential to pay more attention to improving the ease and quality of obtaining and researching migration data, which would allow greater comparability between member states and their trends at the EU level.

Our data primarily refer to Slovenia as a case study of a small country, and for this purpose it is important that they are also available in the international literature on the topic, and thus may contribute to comparative analyses with other small countries in this field in the future.

From the data on the involvement of the SAF in the migrant crisis that were accessible on the official website of the military, in the Archive subsection, and in the annual reports of the Ministry of Defence, we were able to present the intensity of their arrangement at the border control since 2016. We found the appearance of the SAF in the migrant crisis extremely interesting with regard to the difference between this and the classic role they have in society and for the state.

\section{A Quantitative Approach to Migration in the Republic of Slovenia}

As mentioned above, Slovenia dealt with illegal border crossing before 2015, but the numbers of migrants were much smaller than those at present. In 2007 Slovenia entered the Schengen zone, transferring the EU's border to Slovenia's southern border with Croatia. In that year 2,479 illegal migrants were caught at the border with Croatia, according to official police data [16]. During the next eight years there were on average 1,154 illegal migrants a year. Their number peaked in 2012 when the police caught 1,385 migrants. In 2007 the illegal migrations were mostly from Serbia (875), Albania (424), Macedonia (200), and Turkey (200). After that illegal migration from those countries dropped, but in 2008 illegal migrations from Kosovo began. In 2010, migrants from Afghanistan (54) started to come illegally to Slovenia. People from Pakistan (41) came for the first time in 2011, from Somalia (128) and Algeria (122) in 2012, and from Syria (63) and Eritrea (56) in 2013. The following year the most illegal migrants came from Albania (150) [16].

\subsection{Asylum Requests in Slovenia during the Period 2015-2019}

Slovenia received 227 requests for asylum in 2015, 1,308 in 2016, 1,476 in 2017, 2,875 in 2018, and 1,802 by the end of June 2019; a total of 7,488 migrants in the past five years.

Asylum requests in Slovenia between 2016 and 2019

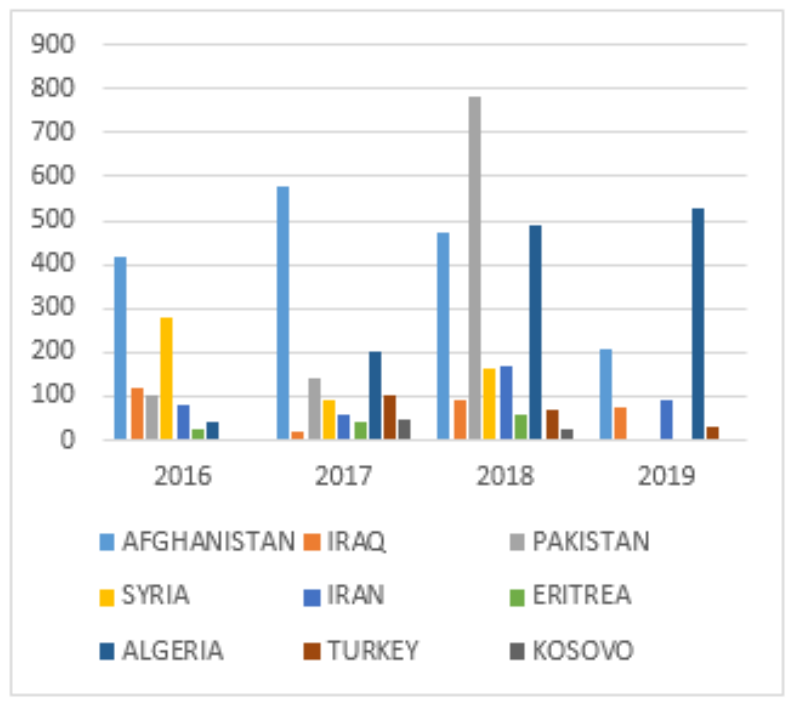

Figure 1. Asylum requests in Slovenia during 2016-2019², according to the countries most people came from

2 The data for 2019 are only up to the end of June. 
As seen in Figure 1, the requests for asylum came from migrants from different countries in different numbers and in unpredictable waves, so it is quite hard to predict what the situation will be in the next few months or years.

\subsection{Illegal Migrations in Slovenia in the Period 2015-2019}

In the autumn of 2015, 334,838 illegal migrants crossed the Slovenian border and territory. Of these, 166,136 people were from Syria, 109,211 from Afghanistan and 59,491 from Iraq. There were also others, but the numbers were comparatively insignificant [17].

For the next two years, it can be seen that migrant pressure was not as strong.

Illegal migration in Slovenia between 2016 and 2019

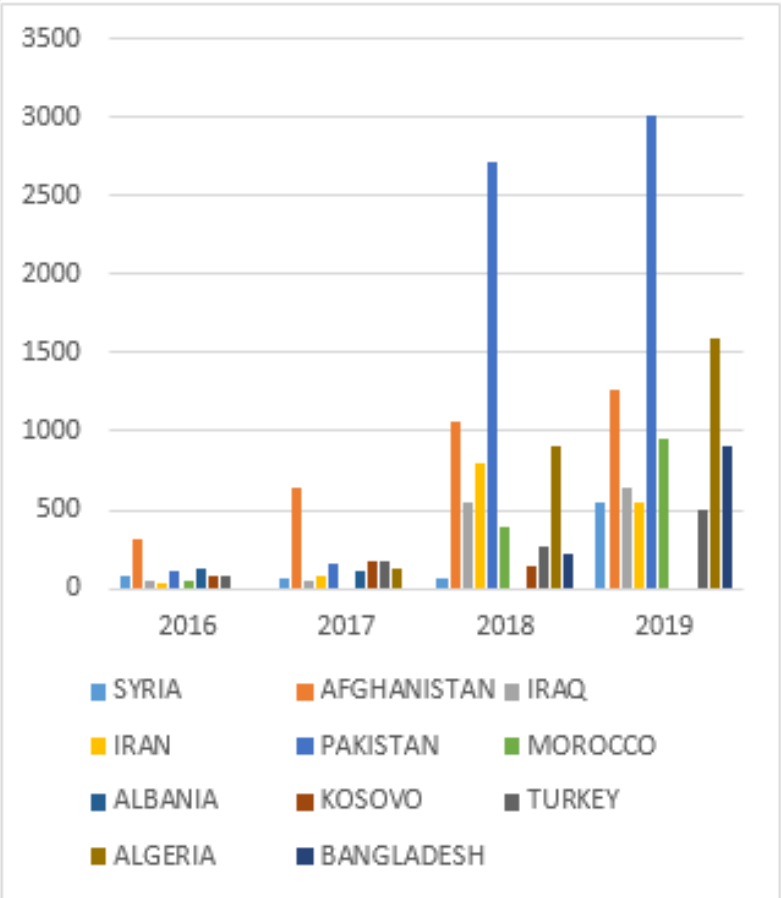

Figure 2. Illegal migrations to Slovenia between 2016 and September 2019, according to police data [18]

The situation has changed considerably since 2018. The numbers of people from Syria, Afghanistan, Iraq, Iran, and Algeria have risen again, and the numbers of people from Pakistan are high in relation to the other states. Bangladeshi migrants did not appear in the statistical records. The data for 2019 are only available up to September. So far, illegal migrants from Albania and Kosovo have not appeared in the numbers they frequently did in previous years.

The main problem is that the numbers of illegal migrants are getting higher each year. There were 1,148 in 2016 and 1,930 in 2017, but in 2018 the number of migrants increased to 9,149 and by the end of September 2019 11,786 illegal migrants had been processed by the police. It would be interesting to know how many of them were not caught during their travel through Slovenia. Altogether there have been 24,013 illegal migrants in the past four years, excluding those that came in 2015 [19].

The police force had a total of 8,171 personnel in 2015 and 8,118 in 2019 [20].

\subsection{Economic Migration to Slovenia in the Period 2015-2019}

As mentioned in previous sections, Slovenia has been recognized as a "promised land" for people from the Western Balkans since the second half of the $20^{\text {th }}$ century.

In the period after 2007, when Slovenia's southern border became the Schengen border of the EU, people from the ex-Yugoslavia republics were among the most frequent illegal migrants to Slovenia. Since then they have been coming to Slovenia as economic migrants with a status of permanent or temporary residence for foreigners.

Permits for permanent and temporary residence for foreigners between 2016 and 2019

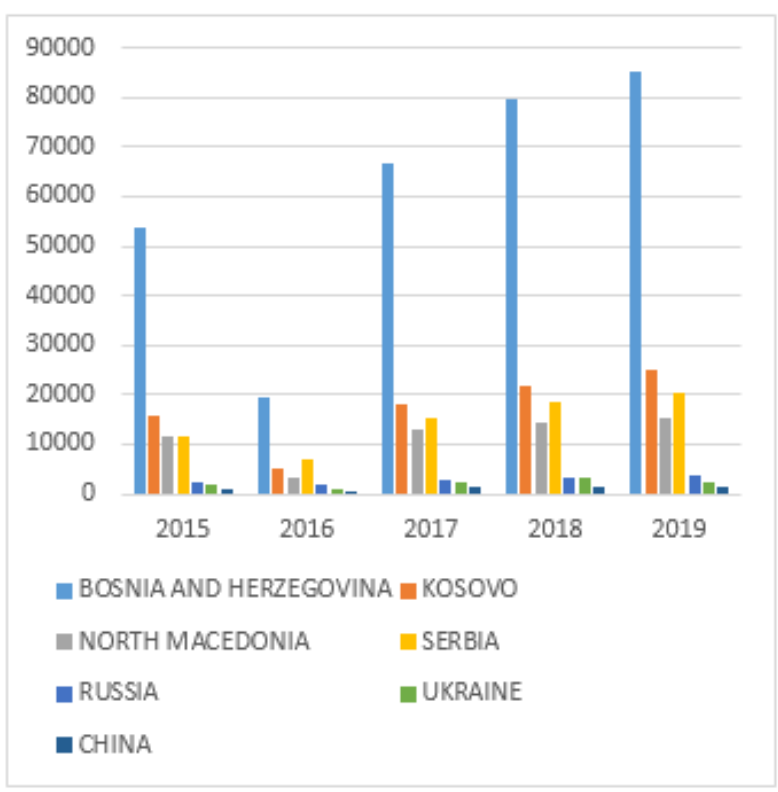

Figure 3. The data show the countries from which the most people came to work in Slovenia in past five years

People come to Slovenia as economic migrants from other countries, too, and there are also other reasons for their moving to Slovenia, but in this article we are discussing economic migrations from the so-called third world countries, not from other EU countries. Permits for permanent and temporary residence for foreigners have been growing in the past five years. At the end of 2015 these permits numbered 102,490, in 2016, 39,748, in 2017, 124,432 , by the end of $2018,148,014$, and up to only the end of June 2019 there had already been 159,363 applications for permanent or temporary residence. In 2018, Slovenia had a population of 2,084,000 people, so the proportion of economic migrants in the country is $7.6 \%$ [21]. 


\subsection{The Role of the Slovenian Armed Forces}

It was stated in a defence policy document that in 2015 the SAF should have a total of 9,100 members: 7,600 in the permanent structure and 1,500 in the reserve component. In fact, there were 7,915 of them: 7,055 in active component and 860 in the contract reserve [22].

The SAF supported the migrant crisis in three phases: the first, which started on 19 October, supporting the police in dealing with the migrant flow; the second from 21 November when they began the construction, operation, and maintenance of physical obstacles on the border (which remains in progress); and the third phase, which started on 15 February and is also still in progress, patrolling the borders with the police.

Since the beginning the SAF has involved its members in tasks connected to the migrations 100,950 times. By the end of 2017, 790 members were activated on daily basis. They have patrolled 2,710,510 kilometres with their vehicles, at a cost of $€ 363,340$ for fuel, and an additional $€ 10,171$ for aircraft costs. During that time, they have organized 25,295 border patrols with the police, which includes 42,306 tasks assigned to SAF members.

As of October 2019, the SAF has 7,154 members: 6,445 in the active component and 709 in the contract reserve [22].

\section{Discussion}

Using a comparative analysis of the different official data from Slovenian police statistics and annual reports, we found that the largest population coming to Slovenia during the past twelve years have been economic migrants from the former republics of Yugoslavia. Today those countries are the Republic of Bosnia and Herzegovina, the Republic of Serbia, the Republic of North Macedonia ${ }^{3}$, the Republic of Montenegro, the Republic of Croatia and the Republic of Kosovo.

They came to the country in different ways after Slovenian independence, but in the period after 2007, when Slovenia became the southern EU border, many of them came as illegal immigrants. In 2008, when Kosovo announced its independence, the number of illegal migrants from there became the largest of the former Yugoslavian republics. Soon thereafter the profile of illegal migrants changed considerably. In the years before the European migrant crisis, the Slovenian government began to look for new economic migrants as a work force with the use of permits for permanent and temporary residence for foreigners. It must be stressed that the profile of the foreigners with this status in Slovenia is quite vast [21], but the largest numbers are still from the countries of the Western Balkans. Language is very

3 Previously the Former Yugoslavian Republic of Macedonia. important here; there are differences between the Slavic languages, but there are many similarities, making them easier to learn than French, German or some other languages.

\subsection{Asylum Seekers in Slovenia and the Response for the Future}

Slovenia adopted its institutions and their functioning according to the solutions that were agreed at the EU level. The European Migrant Network (EMN) [23] reports that some key findings were established in response to increased numbers of asylum seekers in member states, such as strengthened co-operation among relevant stakeholders at the national level. At the bilateral, multilateral, regional and European levels, border control and law enforcement measures were mostly interlinked. Greater reception services and significant legislative and policy amendments were proposed, and procedures were also adopted to speed up and simplify the processing of asylum applications, following the peaks of the influx, with an emphasis on return and integration.

This is also what Slovenia did as a member state. The Office for the Support and Integration of Migrants [24] was established; it carries out the tasks defined by the laws governing the aliens, and the international and temporary protection of displaced people. Within the scope of its functions, it co-ordinates the work and tasks of other national authorities, NGOs and other organizations with regard to the support as well as the integration of migrants, and monitors migration problems. It launches initiatives and proposals for solving the problems in this domain. On the Slovenian website there is a section marked with statistics where we can see the data up to the middle of July 2019; at that time 97 foreigners were waiting to complete a request for asylum, 311 were accommodated as asylum seekers, and 680 had had their asylum status approved [16].

\subsection{Illegal Migrations to Slovenia in the Future}

Following the data on illegal migrations for the past four years, the only prediction that we can make is that the illegal migration flow will keep on rising. As we can see from the police report [16] of September 2019, the number of illegal migrants was $70 \%$ higher than at the same time in 2018. Only 3,856 illegal migrants from September 2019 indicated that they would actually seek asylum in Slovenia. Most of them were from Algeria. The number of asylum seekers is $5 \%$ higher than last year. A total of 650 foreigners who did not have the proper documents to be in the country were caught inside the country or on leaving the Schengen border to go further into the EU; 3,397 foreigners were not allowed to come into the country through the Croatian border for the same reason. The number of these situations were increased by $13.8 \%$ in 2018. 
The Slovenian police caught 4,151 people with unauthorized residence in Slovenia or other countries of the EU by the end of September 2019, an increase of $18.3 \%$ on 2018. So far, 8,050 foreigners have been returned to the Croatian authorities according to international agreements, most of whom were from Pakistan. Slovenia received 491 people according to the same agreements. The police reports include the remark that many of the asylum-seekers soon left for other destinations once they had got into the country [16].

\subsection{Economic Migrations to Slovenia in the Future}

Slovenia needs a work force, particularly for those jobs that Slovenes do not want to do. For people in the Western Balkans, the incomes in Slovenia are still higher than in their own countries. In consequence, we can predict that the numbers of economic migrants from this area will continue to rise in the future. After all, when a person is in an EU country, according to the law one's family can join them. Being a citizen of the EU enables one to move and work freely within the EU borders. Nevertheless, Slovenia is dealing with many different challenges brought on by migration, such as the need to quickly develop housing, schools, kindergartens, health care facilities, more social workers, labour legislation, and an improved pension system. The main problem that occurs relates to language, especially in the case of economic migrants from Kosovo. Their language is quite different to Slovene and their introduction to society is much harder than for those from other Balkan countries [4].

\subsection{The Role of the Armed Forces in the Future}

As mentioned earlier, and according to Garb [7], the Defence Act was changed in 2015 to enable the armed forces to support the police to address the effects of migration. Article 37 states that the SAF should provide assistance in protection and rescue in natural and other disasters, and support the police and other state agencies at the government's discretion. This Article came into force in autumn 2015, and since then the SAF has supported the police to act in the different cases that might occur at the border during the patrols without the need for any extra legislation.

The numbers of military personnel are reducing, but the missions of the SAF connected to the migration crisis are becoming more complex. On 23 September the SAF [27] published news about more activities on the border: "Patrolling with the police will dedicate daily support to the police in the prevention of illegal migration, and the capacity of two infantry companies, responding again to the increased demands of the police. In addition, since 19 August, the Slovenian Armed Forces has been supporting the Police in protecting the state border with the Bell 206 crew and helicopter to observe the border area. The seconded members mostly use the assets of the Slovenian Armed Forces in their work, from observation equipment to armoured vehicles".

\section{Conclusions}

Undoubtedly, the Republic of Slovenia, as a small EU member state, organized itself well during the European migrant crisis, despite the extremely large number of migrants who crossed its territory. In due time, it approached the EU institutions, which came to its aid, but had to organize itself with limited resources until the EU assistance was activated. It also included its armed forces, which for the first time in the history of the country were faced with this kind of mission in their homeland. The SAF had already carried out similar tasks on various international operations and missions in other countries, and its activation during the European migrant crisis was only another experience, which unfortunately is still ongoing. The welcome circumstance was that the mass migration at the beginning of 2016 reduced, otherwise the Slovenian national security system would not have endured.

The EU has taken many measures and made arrangements at the EU level and with the member states within the field of the CSDP, and thus also in the area of migration; but given the recent trends in this area, and in particular in the area of foreign policy, it seems that so far it simply is not enough. Do we need more EU input in the area of migration? In the case of the Republic of Slovenia as a small country, the answer is definitely YES. Small countries, with their limited spatial, human, accommodation and other resources, are simply not able to cope with mass migration. Small countries can and should do their utmost to tackle the migrant crisis jointly, including by using the armed forces, especially at home. Obviously, new security trends require the involvement of members of the armed forces, even though this approach reminds us of other times and the trends of the past. Certainly the EU will have to do more in the area of common foreign policy and make a significant contribution to tackling the original problem of mass migration. Unfortunately, this is just one of the many issues faced by the EU, and each one requires thorough consideration and a great deal of motivation and coordination between all participants, assuming, of course, that they are interested in a broader common interest in addition to their own interests. This means that small countries will continue to be much more exposed to the problems of mass migration.

The Slovenian police force managed to strengthen its financial, personal and equipment resources after the crisis with the help of its union, despite the fact that they organized a strike during the European migrant crisis. According to the Defence Act, the SAF is not allowed to 
strike, so it was not as successful as the police union in this regard. Its personnel, equipment and budget have been reduced continuously for the past ten years since the global financial crisis. In fact, the defence budget has risen slightly since 2016, but for the previous ten years investments in defence were minor [28]. In the event that the trends of the migrations continue, and the facts show these trends, the main question is who will deal with the migrants at the borders if the Slovenian national defence system does not change. There are many other issues that are also of great importance, like financing the migrants, organizing settlements for them, and facilitating their involvement in society. This could be manageable, but only if their numbers are not too large.

Their free movement on an illegal basis all over the country increases crime, violence, accidents, injuries, and death for the migrants and others that might be involved. After all, most of them come from countries of war and conflict with difficult stories, so conflicts and resentments travel with them and could stay with them for good.

Another problem is that the EU did not prepare itself for such a situation, despite the fact that the migrant crisis was on the horizon of North Africa for quite some time. The Republic of Slovenia cannot change much alone because the problem of migration is vast and will continue for quite some time.

Slovenia, as a small country in the EU, and its CSDP need a strategy that will work for the EU and the member states. The huge numbers of migrants in Turkey and Greece demands a policy, not only the EU CSDP but an EU strategic internal policy. External EU policy in the area of migration is of great importance, not only for the small states within the EU and the ones on the routes to it, but also for the fragile Balkan neighbourhood. As far as migration is concerned, more EU input is needed not only on policy matters but also, and most importantly, at the political level of the EU and its cooperation with others in designing peace and security in the migrants' countries of origin.

\section{Acknowledgements}

The research for this article has benefited from the support of the Slovenian Research Agency within the framework of the research project No. J5-1791 (A). "An integral theory on the future of the European Union."

\section{REFERENCES}

[1] J. Zupančič. The European Refugee and Migrant Crisis and Slovenian Response, European Journal of Geopolitics, 4, 2016, pp 95-121.

[2] I. Mikuž. Influence small state force design. United States
War College. Strategy research project, international fellow. https://apps.dtic.mil/dtic/tr/fulltext/u2/a561427.pdf, 2012.

[3] A. Lulle, E. Ungure. Asylum seekers crisis in Europe 2015: debating spaces of fear and security in Latvia. Journal on Baltic Security. Vol. 1, Issue 2, 2015, pp 62-95.

[4] A. Kralj. Unwanted? Media and political constructions of foreigners in Slovenia (original Nezaželeni? Medijske in politične konstrukcije tujcev v Sloveniji), 2008, pp 169-190. Dve domovini. https://www.dlib.si/details/URN:NBN:SI:d oc-WZOKPPLL

[5] S. Šelo Šabić. The Impact of the Refugee Crisis in the Balkans: A Drift towards Security, Journal of Regional Security (2017), Belgrade Centre for Security Policy, 12:1, pp 51-74.

[6] Đ. Luša. Small States and the Big European Migration Crisis: The Open Borders Challenge, Teorija in praksa, let. 56, 2/2019. Faculty of Social Science, Ljubljana.

[7] M. Garb. Coping with the refugee and migrant crises in Slovenia: the role of the military. Defence \& Security Analysis, 2018, 234-1, 3-15, DOI:10.1080/14751798.2018 .1421400

[8] R. Svetlič. Migrations between the right to asylum and the fact of the state. All about people: interdisciplinarity, transnationality and building bridges. Proceeding book with peer review. Alma mater Europae, $5^{\text {th }}$ International Scientific conference, Maribor, 10-11. 3. 2017, pp 120-126.

[9] L. Brožič. European migrant crisis 2015 in selected Slovenian printed media. VI International scientific doctoral conference, conference proceedings, 18 May 2017, 17-24. Available online at https:/www.evropf.si/media/website/2013/04/ZB_DR_FDS_FINAL.pdf.

[10] M. Ceccorulli, S. Lucarelli. Securing borders, saving migrants: the EU's security dilemma in the 21st century. EU security strategies. Extending the EU system of security governance. S. Economides, J. Sperling (Eds.). Routledge studies in European security and strategy, 2018, pp 162-180.

[11] D. Resteigne, P. Manigart. Boots on the streets: a "policization" of the armed forces as the new normal. J. Military Stud. 2019; 8 (special issue): pp 16-27. DOI 10.2478/jms-2019-0003.

[12] The Common Security and Defence Policy Handbook. Schultz und Hilfe. Volume I, 3th edition, 2017, pp 104-112.

[13] Migrations in numbers (Migracije v številkah), Available online athttp://vlada.arhiv-spletisc.gov.si/fileadmin/dokum enti/si/projekti/2015/begunci/160202_migranti.pdf.

[14] R. Bellais. The European refugee and migrant crisis as an asymmetric conflict: what border management can learn from military operations. Conference "Borders, walls and violence: costs and alternatives to border fencing” (UQAM, 2-3 June, 2016, pp 1-7).

[15] A. Cottey. The EU's Common Security and Defence Policy. Institutions without strategy. EU security strategies. Extending the EU system of security governance. S. Economides, J. Sperling (Eds.). Routledge studies in European security and strategy, 2018, pp 125-143. 
[16] Policija. Official website of the Slovenian police. Available online at https://www.policija.si/o-slovenski-policiji/statist ika/mejna-problematika/nedovoljene-migracije-na-obmocj u-republike-slovenije.

[17] Illegal migration in Slovenia in 2015. Available online at https://www.policija.si/images/stories/Statistika/MejnaPro blematika/IlegalneMigracije/2015/December2015.pdf.

[18] Illegal migration in Slovenia. Available online at https://www.policija.si/eng/areas-of-work/border-matters-a nd-foreigners/illegal-migration-statistical-data.

[19] Illegal migration in Slovenia in 2015. Available online at https://www.policija.si/images/stories/Statistika/MejnaPro blematika/IlegalneMigracije/2015/December2015.pdf.

[20] Slovenian Police Report for 2015, 68. Available online at https://www.policija.si/images/stories/Statistika/LetnaPoro cila/PDF/LetnoPorocilo2015_popravljeno.pdf.

[21] Republic of Slovenia, Ministry for Internal Affairs, Foreigners in Slovenia, statistics. Available online at http://mnz.arhiv- spletisc.gov.si/si/mnz_za_vas/tujci_v_slo veniji/statistika/

[22] Ministry of Defence of the Republic of Slovenia, Annual Report for 2015, 6, Available online at http://mo.arhiv-sple tisc.gov.si/fileadmin/mo.gov.si/pageuploads/pdf/ministrstv o/LP_MO_2015.pdf

[23] How did member states react to the fluctuations of the influx of asylum seekers? EMN flash \#2/2018 Introduction to the EMN Study on the Changing Influx of Asylum Seekers 2014-2016. Available online at http://emm.si/wp-content/u ploads/00_eu_changing_influx_flash_en.pdf.

[24] Republic of Slovenia. Office for the Support and Integration of Migrants. Available online at http://uoim.arhiv-spletisc. gov.si/en/areas_of_work/index.html

[25] Annual Report of the Slovenian Ministry of Defence 2015, 7. Available online at http://mo.arhiv-spletisc.gov.si/fileadmi n/mo.gov.si/pageuploads/pdf/ministrstvo/LP_MO_2015.pd

[26] Slovenian Armed Forces. About the Slovenian Armed Forces.http://www.slovenskavojska.si/en/about-the-sloven ian-armed-forces/, September 2019.

[27] Slovenian Armed Forces continue to support the police in protecting the state border. About the Slovenian Armed Forces.http://www.slovenskavojska.si/en/about-the-sloven ian-armed-forces/, September, 2019.

[28] B. Furlan, Z. Barjaktarević. NATO and Slovenia 15 years on: How accurate were the projections about defence expenditure? pp 97-108, Contemporary Military Challenges, 2019, 19/3. DOI: 10.33179/BSV.99.SVI.11.CMC.21.3.5. Online available http://www.slovenskavojska.si/fileadmin/ slovenska_vojska/pdf/vojaski_izzivi/2019/sv19_03.pdf. 